Tsaqofiya : Jurnal Pendidikan Bahasa dan Sastra Arab

Vol. 4 No. 1 Januari 2022, 113-126

P-ISSN : 2685-7022, E-ISSN : 2685-7103

DOI: $10.21154 /$ tsaqofiya.v4i1.47

\title{
Perspektif Filosofis Penelitian Bahasa Arab; Kajian Pembelajaran Bahasa dengan Metode Terjemah
}

\author{
Mohammad Yusuf Setyawan \\ UIN Sunan Kalijaga Yogyakarta \\ mohammadsetyawan22@gmail.com
}

\section{Abstract}

This article aims to provide an overview of the philosophical review in Arabic language research. The focus of the research is the study of language learning with the translation method (tariqah al-tarjamah). The study of language was first carried out by philosophers and not linguists. Since ancient times, philosophers have tried to solve philosophical problems with an analytical approach to language. After linguistics is able to stand alone as a solid field of science, the role of philosophy remains firmly rooted. This research is a qualitative research using descriptive-narrative method. This research will examine the nature of linguistics and language learning studies, methods of language learning studies, and the measurement of the truth of language learning studies. The results of the study show that philosophical review in Arabic language research is very helpful in revealing the nature, methods, and measures of truth in the study of Arabic learning. In essence, linguistics is the science of language or the science that takes language as its object of study. The study of language learning aims to find solutions to improve language teaching outcomes. The method used is included in the systematic scientific method which includes the formulation of the problem, the preparation of a framework of thinking in submitting hypotheses, formulating hypotheses, testing hypotheses, and drawing conclusions. The size of the truth is based on the formulation of logical thinking and unified deductive and inductive logic.

Keywords: philosophy of science, Arabic language, translation method.

\section{Asbtrak}

Artikel ini bertujuan untuk memberikan gambaran tinjauan filosofis dalam penelitian bahasa Arab. Fokus penelitian ini adalah kajian pembelajaran bahasa dengan metode penerjemahan (țarīqah al-tarjamah). Tinjauan filosofis dalam kajian bahasa Arab tentunya sangat diperlukan dalam meningkatkan kualitas pembelajaran bahasa Arab. Penelitian ini merupakan penelitian kualitatif dengan menggunakan metode deskriptif-naratif. Penelitian ini akan mengkaji hakikat kajian linguistik dan pembelajaran bahasa, metode kajian pembelajaran bahasa, dan pengukuran kebenaran kajian pembelajaran bahasa. Hasil kajian menunjukkan bahwa kajian filosofis dalam penelitian bahasa Arab sangat membantu dalam mengungkap hakikat, metode, dan ukuran kebenaran dalam kajian pembelajaran bahasa Arab. Pada hakikatnya linguistik adalah ilmu bahasa atau ilmu yang menjadikan bahasa sebagai objek kajiannya. Kajian pembelajaran 
bahasa bertujuan untuk mencari solusi untuk meningkatkan hasil pengajaran bahasa. Metode yang digunakan termasuk dalam metode ilmiah sistematis yang meliputi perumusan masalah, penyusunan kerangka berpikir dalam mengajukan hipotesis, merumuskan hipotesis, menguji hipotesis, dan menarik kesimpulan. Ukuran kebenaran didasarkan pada rumusan berpikir logis dan kesatuan logika deduktif dan induktif

Kata Kunci: filsafat ilmu, bahasa arab, metode penerjemahan

\section{PENDAHULUAN}

Bahasa Arab merupakan salah satu bahasa asing yang mendapatkan banyak perhatian di kalangan para peneliti dan akademisi di Indonesia. Posisinya sebagai bahasa Al-Qur'an dan bahasa Internasional telah mendorong para peneliti untuk terus menggali lebih dalam perihal bahasa Arab, baik dari segi struktur internal, pemakaian, dan pembelajaran. Di Indonesia, pembelajaran bahasa Arab difokuskan di madrasah-madrasah mulai dari MI, MTs, hingga MA sebagai lembaga pendidikan formal di bawah naungan Kementerian Agama. Di jenjang perguruan tinggi, bahasa Arab diajarkan di Perguruan Tinggi Keagamaan Islam atau Perguruan Tinggi yang memiliki program studi Bahasa dan Sastra Arab, Sastra Arab, dan Pendidikan Bahasa Arab. ${ }^{1}$

Selain di jenjang pendidikan formal, bahasa Arab juga diajarkan secara intensif di pondok pesantren maupun di lembaga kursus bahasa Arab. Hanya saja di era globalisasi ini, bahasa Arab bukanlah bahasa asing satu-satunya yang menarik minat masyarakat. Ini menjadi bahan catatan bagi para pemerhati dan peneliti bahasa Arab agar mampu memberikan kontribusi yang lebih serius untuk meningkatkan kompetensi bahasa Arab bagi para peserta didik. ${ }^{2}$ Menurut Azhar Arsyad, bagi nonArab, apalagi yang bahasanya bertuliskan Latin, masalah penulisan (al-khațt al-'Arabī wa al-așwāt) atau "Arabic script and the sounds which do not exist in other languages" merupakan suatu musykilah tersendiri. Kenyataan lain adalah bahasa Arab mempunyai dua macam bahasa yang berlainan satu sama lain dalam banyak hal; bahasa Arab 'Āmmiyyah dan Fuṣh $\bar{a}^{3}$

${ }^{1}$ Burhan Yusuf Habibi and Wakhidati Nurrohmah Putri, "Pengembangan Buku Ajar Bahasa Arab Berbasis Pada Nilai-Nilai Islam-Indonesia Di IAIN Salatiga," Tsaqofiya: Jurnal Pendidikan Bahasa Dan Sastra Arab 3, no. 1 (2021): 26-45.

2 Novi Mutmainah and Lina Marlina, "Implementasi Metode Mubasyarah Dalam Pembelajaran Muhadatsah," Tsaqofiya: Jurnal Pendidikan Bahasa Dan Sastra Arab 2, no. 2 (2020): 138-51.

${ }^{3}$ Azhar Arsyad, Bahasa Arab dan Metode Pengajarannya (Yogyakarta: Pustaka Pelajar, 2010), 136-137. 
Tinjauan filosofis dalam kajian bahasa Arab tentunya sangat diperlukan dalam meningkatkan mutu pembelajaran bahasa Arab. Fisafat ilmu pengetahuan (falsafah al-'ulūm) adalah cabang filsafat yang mempersoalkan dan mengkaji segala persoalan yang berkaitan dengan ilmu pengetahuan. Jadi yang dipersoalkan, misalnya, apa itu kebenaran? Apa metode ilmu pengetahuan itu? Manakah metode yang paling bisa diandalkan? Apa kelemahan metode yang ada? Apa itu teori? Apa itu hipotesis? Apa itu hukum ilmiah. Berkaitan dengan pertanyaan-pertanyaan terakhir ini, ilmu pengetahuan dilihat sebagai upaya untuk menjelaskan hubungan antara berbagai hal dan peristiwa dalam alam semesta ini secara sistematis dan rasional (masuk akal). ${ }^{4}$

Penelitian terkait perspektif filosofis bahasa Arab telah dilakukan oleh beberapa peneliti sebelumnya. Sholihudin Al Ayubi dalam artikel ilmiahnya yang berjudul "Hubungan Filsafat dan Bahasa Arab (Studi Tentang Keterkaitan Filsafat dan Bahasa Arab)" tahun 2019 menemukan bahwa bahasa Arab merupakan cabang ilmu pengetahuan yang mengandung aspek yang luas, dalam arti bukan mengandung aspek linguistik semata tetapi juga aspek filosofis sehingga benar jika ada keterkaitan erat antara filsafat dan bahasa Arab baik dari aspek ontologis, espitemologis, dan aksiologis. $^{5}$

Sampiril Taurus Tamaji dalam artikelnya yang berjudul "Pembelajaran Bahasa Arab dalam Perspektif Filsafat Ilmu" tahun 2020 menemukan bahwa semua ahli filsafat sepakat bahwa ada hubungan yang erat antara filsafat dan bahasa terutama yang berhubungan dengan peran pokok filsafat sebagai analisator konsep-konsep. ${ }^{6}$ Lalu Tati Nurhayati dalam artikel berjudul "Posisi Ilmu Bahasa Arab dalam Kajian Islam (Perspektif Filsafat Ilmu)" tahun 2020 menemukan bahwa untuk mengetahui posisi ilmu bahasa Arab dalam kajian Islam, maka dapat merujuk pada epistemologi dalam kajian Islam, terutama epistemologi bayani karena di dalamnya, sumber kebenaran dalam kajian Islam terletak pada teks, baik teks Al-Qur'an, hadis, maupun karya para ulama. ${ }^{7}$

\footnotetext{
${ }^{4}$ A. Sonny Keraf dan Mikhael Dua, Ilmu Pengetahuan: Sebuah Tinjauan Filosofis (Yogyakarta: Kanisius, 2012), 23.

${ }^{5}$ Sholihudin Al Ayubi, "Hubungan Filsafat dan Bahasa Arab (Studi Tentang Keterkaitan Filsafat dan Bahasa Arab)," Jurnal Fikroh 12, no. 1 (2019): 54-76.

6 Sampiril Taurus Tamaji, "Pembelajaran Bahasa Arab dalam Perspektif Filsafat Ilmu," AlFakkaar 1, no. 2 (Agustus 2020): 80-104.

7 Tati Nurhayati dan Misnatun Misnatun, "Posisi Ilmu Bahasa Arab dalam Kajian Islam (Perspektif Filsafat Ilmu),” Tafhim Al-'Ilmi 12, no. 1 (30 September 2020): 112-20, https://doi.org/10.37459/tafhim.v12i1.4030.
} 
Ilmu bahasa dan filsafat selalu memiliki hubungan yang erat. Kajian bahasa pertama kali justru dilakukan oleh para ahli filsuf dan bukan ahli bahasa. Sejak zaman dahulu, para filsuf mencoba untuk memecahkan masalah-masalah filsafat dengan pendekatan analisis bahasa. Artikel ini akan membahas kajian pembelajaran bahasa Arab dengan fokus utama pengaruh metode terjemah (țaīqah al-tarjamah) dalam meningkatkan perbendaharaan kata bagi peserta didik. Tinjauan filosofis ini akan membahas hakikat, metode, dan ukuran kebenaran kajian pembelajaran bahasa Arab. Tinjauan ini diharapkan mampu memberikan gambaran kepada para pemerhati bahasa Arab agar mampu meningkatkan kualitas pembelajaran.

\section{METODE}

Penelitian ini merupakan penelitian kepustakaan yang bersifat kualitatif. Penelitian ini menggunakan pendekatan filsafat ilmu dalam memberikan tinjauan filosofis terhadap kajian pembelajaran bahasa Arab yang secara spesifik terkait dengan metode terjemah. Fokus penelitiannya tertumpu pada hakikat linguistik dan kajian pembelajaran bahasa, metode kajian pembelajaran bahasa, dan ukuran kebenaran kajian pembelajaran bahasa. Dalam penelitian ini, metode pembelajaran yang dikaji adalah metode terjemah dengan asumsi bahwa metode ini berpotensi untuk menambah perbendaharaan kata para siswa. Sumber data diambil dari buku dan artikel ilmiah terkait filsafat ilmu dan kajian pembelajaran bahasa Arab. Penelitian ini menggunakan metode deskriptif naratif.

\section{PEMBAHASAN}

\section{Hakikat Linguistik dan Kajian Pembelajaran Bahasa}

Umur kajian tentang bahasa itu sudah tua yang dimulai sejak zaman Yunani Kuno hingga zaman modern. Pada awalnya, para filsuflah yang mengkaji bahasa dan memberikan definisi, kategori, pembedaan jenis, bentuk dan sifat, dan perbedaanperbedaan lainnya. Setelah linguistik mampu berdiri sendiri menjadi suatu bidang ilmu yang kokoh, peranan filsafat tetap mengakar dengan kuat. Meskipun pengkajian bahasa telah diambil alih oleh para linguis namun dimensi-dimensi filsafat tetap menguat di dalamnya. Hal ini disebabkan oleh keyakinan bahwa filsafat bahasa merupakan roh dari ilmu bahasa dalam menemukan teori-teori kebahasaan. ${ }^{8}$

\footnotetext{
8 Tamaji, “Pembelajaran Bahasa Arab dalam Perspektif Filsafat Ilmu," 85.
} 
Linguistik adalah ilmu tentang bahasa atau ilmu yang mengambil bahasa sebagai objek kajiannya. Linguistik mendekati bahasa sebagai bahasa, sebagai satu sistem lambang bunyi yang bersifat arbitrer, unik, produktif, dinamis, dan bervariasi. Sebagai satu sistem bahasa itu mempunyai keteraturan-keteraturan dalam satuansatuannya yang tampil dalam wujud lambang yang berupa bunyi. Keteraturanketeraturan sistem lambang inilah yang ingin dideskripsikan oleh linguistik. ${ }^{9}$

Objek kajian linguistik meliputi tiga hal: (1) kajian terhadap struktur internal bahasa, (2) kajian terhadap pemakaian bahasa, dan (3) kajian terhadap pembelajaran bahasa. Kajian terhadap pengajaran bahasa bertujuan untuk mencari solusi dalam meningkatkan hasil pengajaran bahasa. Maka kajian dalam bidang ini mencakup kajian eksperimental yang mencoba metode atau teknik pembelajaran, mengkaji variabel yang mempengaruhi hasil pengajaran bahasa, mengkaji korelasi antara dua variabel dalam pengajaran bahasa, atau mengkaji butir-butir materi dalam pengajaran bahasa. ${ }^{10}$

Tujuan utama kajian pembelajaran bahasa adalah untuk mengetahui hasil pembelajaran itu, mengetahui kekurangan-kekurangan dalam metode dan teknik pembelajaran, untuk kemudian mengatasinya, demi tercapainya hasil pembelajaran yang lebih baik. Oleh karena itu, objek atau materi yang dikaji meliputi mulai dari metode yang digunakan dalam suatu kegiatan belajar-mengajar (KBM) terhadap hasil belajar, perbandingan hasil belajar melalui dua metode belajar yang berbeda, pengaruh suatu aspek terhadap hasil belajar, hubungan (korelasi) antara dua hasil kegiatan belajar, dan sebagainya. ${ }^{11}$

Bahasa Arab adalah bahasa yang dipakai oleh komunitas (masyarakat) di jazirah Arab yang berjumlah sekitar 250 juta orang. ${ }^{12}$ Pembelajaran bahasa Arab adalah kegiatan transformasi kebahasaaraban melalui proses-proses edukatif yang dijabarkan melalui strategi, langkah, teknik, dan lain-lain di lembaga pendidikan. Pembelajaran bahasa Arab dapat dilihat dari lima segi: ketenagaan, peserta didik, lingkungan, kurikulum, dan sistem. Penelitian pembelajaran bahasa Arab berfungsi untuk hal-hal sebagai berikut:

${ }^{9}$ Abdul Chaer, Kajian Bahasa: Struktur Internal, Pemakaian, dan Pemelajaran (Jakarta: Rineka Cipta, 2013), 12-13.

${ }^{10}$ Chaer, 13.

${ }^{11}$ Chaer, 153.

12 Wildan Taufiq, Metode Penelitian Bahasa Arab (Bandung: Refika Aditama, 2018), 23. 
(1) Mengembangkan ilmu pendidikan bahasa, yaitu aspek-aspek yang berkaitan dengan pendidikan dan pembelajaran bahasa.

(2) Memecahkan masalah pendidikan bahasa, terutama masalah yang berkenaan dengan kualitas proses dan hasil pendidikan dan pembelajaran bahasa Arab.

(3) Mengkritisi kebijakan terkait pendidikan bahasa Arab. ${ }^{13}$

Tidak diragukan lagi bahwa salah satu kunci keberhasilan dalam pembelajaran bahasa adalah metode pembelajaran yang digunakan. Mengingat banyaknya metode dalam pembelajaran bahasa Arab, makalah ini hanya memfokuskan pada metode terjemah (țarīqah al-tarjamah). Metode terjemah yaitu metode menerjemahkan atau dengan kata lain menyajikan pelajaran dengan menerjemahkan buku-buku bacaan berbahasa asing (Arab) ke dalam bahasa sehari-hari dan buku bacaan tersebut tentunya telah direncanakan sebelumnya. Metode ini cocok untuk bagaimana memahami isi dan maksud bukti berbahasa asing dengan kemahiran membaca dan mengerti secara tepat, tidak untuk menggunakan bahasa secara lisan. ${ }^{14}$

Metode terjemah seringkali dipadukan dengan metode gramatika. Metode ini berdasarkan asumsi bahwa ada satu "Logika Semesta” yang merupakan dasar semua bahasa di dunia ini, dan bahwa tata bahasa merupakan bagian dari filsafat dan logika. Belajar bahasa dengan demikian dapat memperkuat kemampuan berpikir logis, memecahkan masalah, dan menghafal. Para pelajar bahasa dengan metode ini didorong untuk menghafal teks-teks klasik berbahasa asing dan terjemahannya dalam bahasa pelajar, terutama teks-teks yang bernilai sastra tinggi, walaupun dalam teks itu sering kali terdapat struktur kalimat yang rumit dan kata-kata atau ungkapan yang sudah tidak terpakai. ${ }^{15}$

Langkah-langkah pelaksanaan metode terjemah ini dapat dilakukan dengan cara guru menunjuk atau menentukan bahan-bahan bacaan yang akan diterjemahkan itu kepada siswa, dan menetapkan pula pokok-pokok atau seri-seri pelajaran yang akan dipelajari. Kalau sudah diketahui bersama oleh siswa topik yang akan diterjemahkan itu maka langkah berikutnya guru memulai membuka seri pertama. Pelajaran baru itu dan menerjemahkannya. Pada tingkat-tingkat dasar sebaiknya

\footnotetext{
${ }^{13}$ Izzuddin Musthafa dan Acep Hermawan, Metodologi Penelitian Bahasa Arab: Konsep Dasar, Strategi, Metode, Teknik (Bandung: Remaja Rosdakarya, 2018), 47.

${ }^{14}$ Wa Muna, Metodologi Pembelajaran Bahasa Arab: Teori dan Aplikasi (Yogyakarta: TERAS, 2011), 94-96.

15 Kamil Ramma Oensyar dan Ahmad Hifni, Pengantar Metodologi Pembelajaran Bahasa Arab (Banjarmasin: IAIN Antasari Press, 2015), 68.
} 
siswa terlebih dahulu diperkenalkan kaidah-kaidah dalam menerjemahkan, jadi jangan langsung menerjemahkan, namun setelah pengetahuan dasar menerjemahkan ini telah dimiliki oleh siswa barulah pelajaran menerjemahkan dapat dimulai. ${ }^{16}$

\section{Metode Kajian Pembelajaran Bahasa Arab}

Dalam perspektif filsafat ilmu, metode kajian pembelajaran bahasa Arab harus berpedoman pada metode ilmiah. Metode ilmiah merupakan prosedur dalam mendapatkan pengetahuan yang dimaksud ilmu. Metode merupakan suatu prosedur atau cara mengetahui sesuatu, yang mempunyai langkah-langkah yang sistemastis. Metode ilmiah merupakan ekspresi mengenai cara bekerja pikiran. Dengan cara bekerja ini maka pengetahuan yang dihasilkan diharapkan mempunyai karakteristikkarakteristik tertentu yang diminta oleh pengetahuan ilmiah, yaitu sifat rasional dan teruji yang memungkinkan tubuh pengetahuan yang disusunnya merupakan pengetahuan yang dapat diandalkan. ${ }^{17}$

Dalam kasus ini, penelitian terkait pelaksanaan metode terjemah bisa langsung dimasukkan ke sistematika metode ilmiah sebagai berikut. ${ }^{18}$

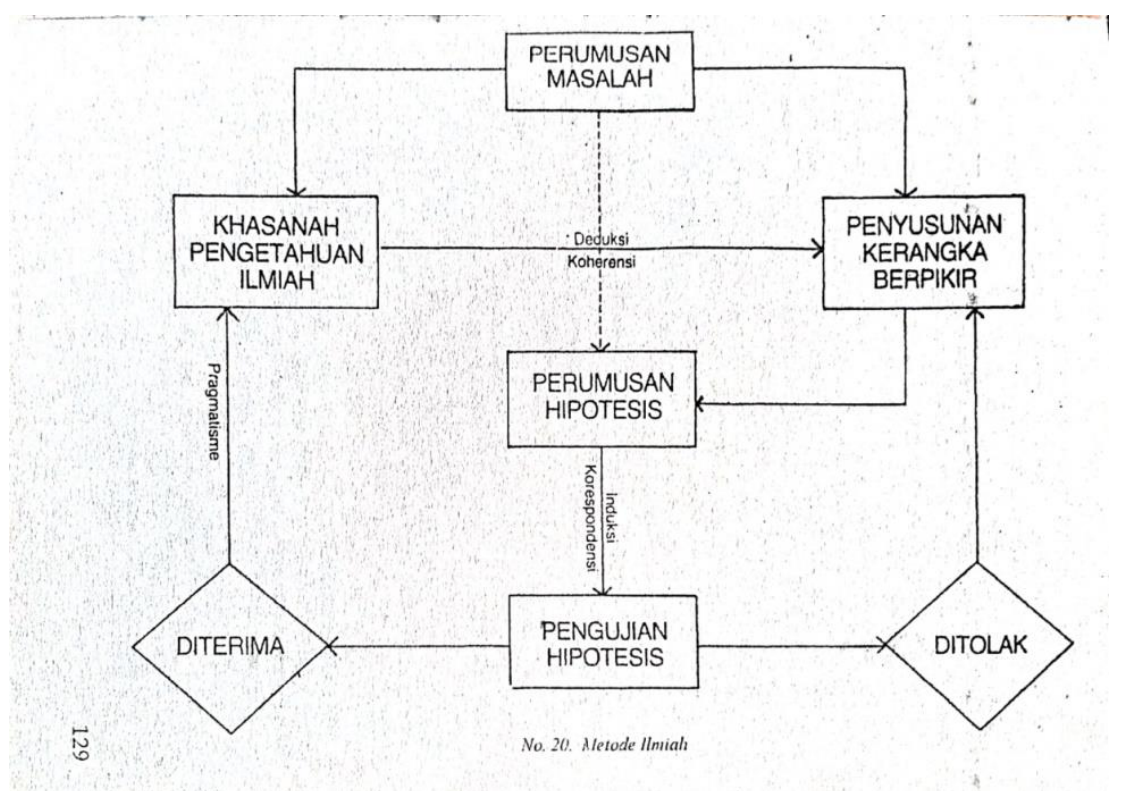

${ }^{16}$ Muna, Metodologi Pembelajaran Bahasa Arab: Teori dan Aplikasi, 95. 2018), 119

17 Jujun S. Suriasumantri, Filsafat Ilmu: Sebuah Pengantar Populer (Jakarta: Sinar Harapan,

18 Suriasumantri, 129. 
a. Perumusan Masalah

Perumusan masalah merupakan pertanyaan mengenai obyek empiris yang jelas batas-batasnya serta dapat diidentifikasikan faktor-faktor yang terkait di dalamnya. ${ }^{19}$ Perumusan ini didapat dari khasanah pengetahuan ilmiah. Segala hal atau kondisi yang berkaitan dengan bidang tertentu sebenarnya bisa menginspirasi munculnya masalah ketika terjadi suatu fenomena menarik dan unik. Namun untuk sekadar gambaran umum, masalah itu bisa muncul melalui bacaan, seminar, diskusi atau pertemuan ilmiah, pernyataan pemegang otoritas, pengamatan, pengalaman pribadi, dan perasaan intuitif. ${ }^{20}$ Contoh rumusan masalah untuk penelitian ini adalah: "bagaimana pengaruh metode terjemah terhadap peningkatan perbendaharaan kata peserta didik kelas X MAN 2 Kudus?"

b. Penyusunan Kerangka Berpikir

Penyusunan kerangka berpikir dalam pengajuan hipotesis merupakan argumentasi yang menjelaskan hubungan yang mungkin terdapat antara berbagai faktor yang saling mengkait dan membentuk konstelasi permasalahan. Kerangka berpikir ini disusun secara rasional berdasarkan premis-premis ilmiah yang telah teruji kebenarannya dengan memperhatikan faktor-faktor empiris yang relevan dengan permasalahan. ${ }^{21}$

Setelah masalah dirumuskan maka perlu dilakukan kajian teori yang berkenaan dengan masalah atau variabel yang dikaji itu. Teori hendaknya diambil dari sumber (buku, jurnal, dan lain-lain) yang terbaru, dan sudah seharusnya dari pakar yang ahli di bidangnya. Teori lama (buku lama) boleh

${ }^{19}$ Suriasumantri, 128.

20 Musthafa dan Hermawan, Metodologi Penelitian Bahasa Arab: Konsep Dasar, Strategi, Metode, Teknik, 103.

${ }^{21}$ Suriasumantri, Filsafat Ilmu: Sebuah Pengantar Populer, 128. 
saja digunakan kalau belum ada teori baru yang "membatalkan" teori lama itu. Keterangan dari kamus umum jangan digunakan sebagai acuan teori karena kamus hanya menjelaskan makna kata; kecuali, barangkali, kamus istilah dalam bidang yang dikaji. Kajian teori dilanjutkan dengan uraian mengenai kerangka konsep. Kerangka konsep ini merupakan kesimpulan dari kerangka teori yang bisa digunakan untuk menganalis atau mengukur data penelitian. ${ }^{22}$ Dalam kasus penelitian ini maka perlu dikemukakan teori tentang metode terjemah termasuk kelebihan dan kekurangannya dan teori tentang perbendaharaan kata.

c. Perumusan Hipotesis

Hipotesis adalah suatu keterangan bersifat sementara atau untuk keperluan pengujian yang diduga mungkin benar dan dipergunakan sebagai pangkal untuk penyelidikan lebih lanjut sampai diperoleh kepastian dengan pembuktian. $^{23}$ Perumusan hipotesis merupakan jawaban sementara atau dugaan terhadap pertanyaan yang diajukan yang materinya merupakan kesimpulan dari kerangka berpikir yang dikembangkan. ${ }^{24}$ Hipotesis disusun berdasarkan kerangka teori. Hipotesis hanya terdapat dalam kajian kuantitatif atau yang menganalisis data kuantitatif dengan menggunakan penghitungan statistik. Kajian yang mencari hubungan antara dua variabel atau lebih, kajian yang mempersoalkan adanya pengaruh, atau yang membicarakan adanya perbedaan, tentu memiliki hipotesis. ${ }^{25}$

Penyusunan hipotesis melibatkan cara berpikir deduktif (al-tafkīr alistintājī . Berpikir deduktif adalah proses logika yang berangkat dari kebenaran umum mengenai suatu fenomena (teori) dan menggeneralisasikan kebenaran tersebut pada suatu peristiwa atau data tertentu yang berciri sama dengan fenomena yang bersangkutan (prediksi). ${ }^{26}$ Berpikir deduktif memberikan sifat yang rasional kepada pengetahuan ilmiah dan bersifat konsisten dengan pengetahuan yang telah dikumpulkan sebelumnya. Cara berpikir deduktif berdasar pada kebenaran koherensi.

22 Chaer, Kajian Bahasa: Struktur Internal, Pemakaian, dan Pemelajaran, 157.

23 The Liang Gie, Pengantar Filsafat Ilmu (Yogyakarta: Liberty Yogyakarta, 2012), 116.

${ }^{24}$ Suriasumantri, Filsafat Ilmu: Sebuah Pengantar Populer, 128.

25 Chaer, Kajian Bahasa: Struktur Internal, Pemakaian, dan Pemelajaran, 157.

26 Musthafa dan Hermawan, Metodologi Penelitian Bahasa Arab: Konsep Dasar, Strategi, Metode, Teknik, 116. 
Dalam konteks penelitian bahasa yang sifatnya deskriptif, hipotesis tidak menjadi keharusan untuk dicantumkan. Namun dalam penelitian bahasa yang fokusnya adalah pengguna, pendidik, atau pelajar bahasa, yang biasanya melibatkan sampel, maka hipotesis menjadi bagian yang harus dilakukan. ${ }^{27}$ Hipotesis akan mengarahkan kerja analisis data selanjutnya. Hipotesis ini bisa mengarahkan jawaban ke arah positif atau ke arah netral.

Berikut ini contoh hipotesis terkait kasus yang diteliti:

(1) Ada pengaruh antara metode terjemah dengan peningkatan perbendaharaan kata peserta didik kelas X MAN 2 Kudus.

(2) Tidak ada pengaruh antara metode terjemah dengan peningkatan perbendaharaan kata peserta didik kelas X MAN 2 Kudus.

Hipotesis yang mengarah pada ada pengaruh, ada perbedaan, atau ada hubungan lazim disebut hipotesis penelitian atau Hp (al-fardiyyah al'amaliyyah) dan hipotesis yang mengarah pada tidak ada pengaruh, tidak ada perbedaan, atau tidak ada hubungan disebut hipotesis nol (al-fardiyyah alșifriyyah).

d. Pengujian Hipotesis

Pengujian hipotesis merupakan pengumpulan fakta-fakta yang relevan dengan hipotesis yang diajukan untuk memperlihatkan apakah terdapat faktafakta yang mendukung hipotesis tersebut atau tidak. ${ }^{28}$ Pengujian hipotesis menggunakan cara berpikir induktif (al-tafkīr al-istiqrāiyyah) yang berdasar pada kebenaran korespodensi. Teori korespondensi menyebutkan bahwa suatu pernyataan dapat dianggap benar sekiranya materi yang terkandung dalam pernyataan itu bersesuaian (berkorespondensi) dengan obyek faktual yang dituju oleh pernyataan tersebut. ${ }^{29}$ Dalam kasus ini maka perlu dilakukan tes, apakah metode terjemah yang telah dipraktikkan mampu memberikan pengaruh terhadap perbendaharaan kata peserta didik kelas X MAN 2 Kudus ataukah tidak.

e. Penarikan Kesimpulan

Penarikan kesimpulan merupakan penilaian apakah sebuah hipotesis yang diajukan itu ditolak atau diterima. Sekiranya dalam proses pengujian

${ }^{27}$ Musthafa dan Hermawan, 124.

${ }^{28}$ Suriasumantri, Filsafat Ilmu: Sebuah Pengantar Populer, 128.

${ }^{29}$ Suriasumantri, 120. 
terdapat fakta yang cukup mendukung hipotesis maka hipotesis itu diterima. Sebaliknya sekiranya dalam proses pengujian tidak terdapat fakta yang cukup mendukung hipotesis maka hipotesis itu ditolak. Dalam penelitian ini maka hipotesis penelitian akan diterima jika didukung oleh hasil tes.

Hasil tes harus menunjukkan bahwa metode terjemah benar-benar memberikan pengaruh terhadap peningkatan perbendaharaan peserta didik kelas X MAN 2 Kudus. Sebaliknya, hipotesis akan ditolak jika tidak didukung oleh hasil tes. Hipotesis yang ditolak ini menunjukkan adanya ketidaktepatan dalam penyusunan kerangka berpikir. Oleh karena itu peneliti perlu melakukan tinjauan ulang dalam proses penyusunan kerangka berpikir.

Hipotesis yang diterima kemudian dianggap menjadi bagian dari pengetahuan ilmiah sebab telah memenuhi persyaratan keilmuan yakni mempunyai kerangka penjelasan yang konsisten dengan pengetahuan ilmiah sebelumnya serta telah teruji kebenarannya. Pengertian kebenaran di sini harus ditafsirkan secara pragmatis artinya bahwa sampai saat ini belum terdapat fakta yang menyatakan sebaliknya. ${ }^{30}$

Dalam kepustakaan metodologi ilmu atau penelitian ilmiah, pengertian metode seringkali disamakan atau dicampuradukkan dengan pendekatan maupun teknik. Metode, pendekatan, dan teknik merupakan tiga hal yang berbeda walaupun bertalian erat satu sama lain. Menurut Vernon Van Dyke, suatu pendekatan pada pokoknya adalah ukuran-ukuran untuk memilih masalah-masalah dan data yang bertalian, sedang metode adalah prosedur untuk mendapatkan dan memeprgunakan data. Pengertian metode tidak pula sama dengan teknik. Metode ilmiah adalah berbagai prosedur yang mewujudkan pola-pola dan tata langkah dalam pelaksanaan suatu penelitian ilmiah. Pola dan tata langkah prosedural itu dilaksanakan dengan cara-cara operasional dan teknis yang lebih terinci. Cara-cara itulah tang mewujudkan teknik. Jadi, teknis adalah suatu cara operasional teknis yang seringkali bercorak rutin, mekanis, atau spesialistis untuk memperoleh dan menangani data dalam penelitian. ${ }^{31}$

Penelitian pembelajaran bahasa Arab menggunakan corak metode kuantitatif (al-baḥs al-kammī). Kajian kuantitatif pada dasarnya digunakan untuk menguji suatu

31 The Liang Gie, Pengantar Filsafat Ilmu, 116-17. 
teori atau hipotesis. Kajian dimulai dengan merumuskan masalah, menentukan teori yang relevan, merumuskan hipotesis, menentukan instrumen, mengumpulkan data, menganalisis data, dan menarik kesimpulan apakah hipotesis itu diterima atau ditolak. Penelitian bahasa yang berkenaan dengan pengajaran bahasa bisa dikuantifikasikan. Dalam penelitian kuantitatif kajian pustaka diperlukan untuk menyusun landasan teori atau kerangka berpikir yang akan digunakan untuk menganalisis data penelitian, serta menguji hipotesis yang diajukan dalam penelitian tersebut.

Dalam penelitian kuantitatif atau penelitian yang bertujuan menguji suatu teori maka penelitian itu harus atau memerlukan hipotesis, sebab komponen utama yang menuntun langkah-langkah penelitian adalah masalah $\rightarrow$ hipotesis $\rightarrow$ data $\rightarrow$ kesimpulan. ${ }^{32}$ Untuk kajian pengajaran bahasa, yang inti kajiannya hasil belajar, datanya tentu berupa angka-angka kuantifikasi, yang dapat diambil dengan tes-tes kemampuan dalam metode pengumpulan datanya. Data itu harus diolah dan dianalisis secara statistik dalam metode analisis datanya. ${ }^{33}$

\section{Ukuran Kebenaran Kajian Pembelajaran Bahasa Arab}

Ukuran kebenaran kajian pembelajaran bahasa Arab pada umumnya dan penerapan metode terjemah pada khususnya, didasarkan pada rumusan berpikir logis yang merupakan ciri dari penalaran. Kegiatan penalaran merupakan suatu proses berpikir logis, dimana berpikir logis di sini harus diartikan sebagai kegiatan berpikir menurut suatu pola tertentu, atau dengan perkataan lain, menurut logika tertentu. ${ }^{34}$ Penalaran ilmiah pada hakikatnya merupakan gabungan dari penalaran deduktif dan induktif, dimana lebih lanjut penalaran deduktif terkait dengan rasionalisme, dan penalaran induktif dengan empirisme. Logika bepikir deduktif dan induktif yang padu ini menjadi ukuran kebenaran pembelajaran bahasa Arab. Logika deduktif digunakan dalam penyusunan kerangka berpikir yang didapatkan dari khasanah pengetahuan ilmiah guna mengajukan hipotesis terkait ada atau tidaknya pengaruh metode terjemah terhadap peningkatan perbendaharaan kata peserta didik kelas X MAN 2 Kudus. Sementara logika induktif digunakan dalam menguji hipotesis yang telah diajukan tersebut.

32 Chaer, Kajian Bahasa: Struktur Internal, Pemakaian, dan Pemelajaran, 31.

33 Chaer, 49.

${ }^{34}$ Suriasumantri, Filsafat Ilmu: Sebuah Pengantar Populer, 43. 


\section{SIMPULAN}

Tinjauan filosofis dalam penelitian bahasa Arab sangat membantu dalam mengungkap hakikat, metode, dan ukuran kebenaran dalam kajian pembelajaran bahasa Arab. Pada hakikatnya, linguistik adalah ilmu tentang bahasa atau ilmu yang mengambil bahasa sebagai objek kajiannya. Kajian terhadap pembelajaran bahasa bertujuan untuk mencari solusi dalam meningkatkan hasil pengajaran bahasa yang dalam contoh kasus ini adalah penerapan metode terjemah dalam meningkatkan perbendaharaan kata peserta didik kelas X MAN 2 Kudus. Metode yang digunakan masuk dalam sistematika metode ilmiah yang mencakup perumusan masalah, penyusunan kerangka berpikir dalam pengajuan hipotesis, perumusan hipotesis, pengujian hipotesis, dan penarikan kesimpulan. Ukuran kebenarannya didasarkan pada rumusan berpikir logis dan logika deduktif dan induktif yang padu.

\section{DAFTAR PUSTAKA}

Habibi, Burhan Yusuf, and Wakhidati Nurrohmah Putri. "Pengembangan Buku Ajar Bahasa Arab Berbasis Pada Nilai-Nilai Islam-Indonesia Di IAIN Salatiga." Tsaqofiya: Jurnal Pendidikan Bahasa Dan Sastra Arab 3, no. 1 (2021): 26-45.

Mutmainah, Novi, and Lina Marlina. "Implementasi Metode Mubasyarah Dalam Pembelajaran Muhadatsah." Tsaqofiya: Jurnal Pendidikan Bahasa Dan Sastra Arab 2, no. 2 (2020): 138-51.

Al Ayubi, Sholihudin. "Hubungan Filsafat dan Bahasa Arab (Studi Tentang Keterkaitan Filsafat dan Bahasa Arab)." Jurnal Fikroh 12, no. 1 (2019): 54-76.

Arsyad, Azhar. Bahasa Arab dan Metode Pengajarannya. Yogyakarta: Pustaka Pelajar, 2010.

Chaer, Abdul. Kajian Bahasa: Struktur Internal, Pemakaian, dan Pemelajaran. Jakarta: Rineka Cipta, 2013.

Keraf, A. Sonny, dan Mikhael Dua. Ilmu Pengetahuan: Sebuah Tinjauan Filosofis. Yogyakarta: Kanisius, 2012.

Muna, Wa. Metodologi Pembelajaran Bahasa Arab: Teori dan Aplikasi. Yogyakarta: TERAS, 2011. 
TSAQOFIYA: Jurnal Pendidikan Bahasa dan Sastra, 4 (1), 2022

Musthafa, Izzuddin, dan Acep Hermawan. Metodologi Penelitian Bahasa Arab: Konsep Dasar, Strategi, Metode, Teknik. Bandung: Remaja Rosdakarya, 2018.

Nurhayati, Tati, dan Misnatun Misnatun. "Posisi Ilmu Bahasa Arab dalam Kajian Islam (Perspektif Filsafat Ilmu)." Tafhim Al-'Ilmi 12, no. 1 (30 September 2020): 112-20. https://doi.org/10.37459/tafhim.v12i1.4030.

Oensyar, Kamil Ramma, dan Ahmad Hifni. Pengantar Metodologi Pembelajaran Bahasa Arab. Banjarmasin: IAIN Antasari Press, 2015.

Suriasumantri, Jujun S. Filsafat Ilmu: Sebuah Pengantar Populer. Jakarta: Sinar Harapan, 2018.

Tamaji, Sampiril Taurus. "Pembelajaran Bahasa Arab dalam Perspektif Filsafat Ilmu." Al-Fakkaar 1, no. 2 (Agustus 2020): 80-104.

Taufiq, Wildan. Metode Penelitian Bahasa Arab. Bandung: Refika Aditama, 2018.

The Liang Gie. Pengantar Filsafat Ilmu. Yogyakarta: Liberty Yogyakarta, 2012. 